\title{
11: Contemporary medical pluralism in Burma
}

\author{
Monique Skidmore
}

\section{Introduction}

Every day in Central Burma, Burmese people engage with their pluralistic medical system. As with medical systems all over the world, in Central Burma, confusing, competing and contradictory logics govern the use of this medical system by Burmese people. Central Burma can be defined as the deltas and valleys of the Ayeyarwady River, where the population is divided between the large population centres of Yangon, Mandalay, Pathein and Mawlamyaing and the many villages that surround the river and its tributaries. The aim in this chapter is to present a cultural understanding of the ways in which Burma's pluralistic medical system has been transformed through the past century or so. It examines the relationship between private and public healthcare systems and controversy about the use and provision of humanitarian and in-country aid, before examining transnational and cross-border forms of health provision accessed by Burmese people in their search for affordable and curative medicines. It seeks to make more complex analysis of the provision of health care by considering how users encounter and negotiate their way through the Burmese medical system. Finally, it considers some of the longer-term consequences that a lack of the right to health is bringing about in Burma.

\section{Overview of the healthcare system}

Burma ranks 190 out of 191 countries in terms of 'overall health system performance' (WHO 2000). ${ }^{1}$ With one psychiatric hospital in the country and one doctor for 2772 people, health care is difficult to come by (WHO 2006). It is also inordinately expensive: of all the South-East Asian nations, Burma ranks first in terms of the amount that individuals spend on health care (80.6 per cent of the total expenditure on health in Burma in 2006) and last in terms of government health expenditure (2.8 per cent of gross domestic product or GDP). The Human Security Report (Human Security Center 2005) defines Burma as the world's most conflict-prone country and the twelfth-least secure in terms of core human rights abuses. Currently, 160000 refugees from Burma reside in seven refugee camps in Thailand, with a further 400000 working as illegal migrants in manufacturing, agricultural and sex industries. Many have become political refugees in countries such as the United States and Australia. Medical doctors continue to leave the country in significant numbers and important international 
healthcare providers, such as Médecins sans Frontières and the Global Fund to Fight Malaria, Tuberculosis, and HIV/AIDS, have recently pulled out of Burma (McGeown 2005), although the Three Diseases Fund is replacing some of their planned activities. The World Health Organisation (WHO 2007) expects HIV/AIDS to become a major cause of death among young adults in Burma in the next decade.

Transparency International (2007) regards Burma as the most corrupt nation on the planet ${ }^{2}$ and, while its Corruption Perceptions Index presents a stark picture of Burma as a whole, it is less revealing of the necessity for hospital workers to steal medicines and supplies and sell them on the black market. The WHO's picture of the Burmese health system is also blunt as it is unable to capture the broad and diffuse effects of corruption and poverty on Burmese health needs and outcomes. These include the existence of up to tens of thousands of child soldiers (CSI 2004), 5000-10 000 female sex workers (Talikowski and Gillieatt 2004:193), human trafficking, food insecurity and extreme poverty (FOWFP 2008), one-third of Burmese children being malnourished (Zeller 2007) and illicit drug production and use (UNODC 2007a:3, 2007b). ${ }^{3}$

A national health committee or council was formed by the new military regime in 1988, and continues to operate with the Prime Minister as its chair. It has responsibility for implementing national health programs, such as the Health Vision 2030 Plan and the current five-year National Health Plan (2006-11). The committee has devised three major changes to health policy since the Ne Win era:

1. a policy of partnering with international, local and para-statal non-governmental organisations (NGOs) to jointly provide healthcare delivery

2. beginning in 1993, a cost-sharing mechanism in which patients pay for medical services and diagnostic and laboratory tests

3. fostering a dual public and private healthcare system. In the public sector, this involves the creation of biomedical and traditional medicine training, licensing, regulation and the provision of hospital, clinic and research facilities. In addition, ministries such as those of defence, railways, mines and industry provide some level of healthcare for their employees. The enabling of a private medical system has recently seen the development of private hospitals such as Pun Hlaing International Hospital and cancer, cardiac and dental clinics.

In terms of national public health, prevention and the regulation of medicines, a major response of the regime has been to enact a series of medical and public health laws in the past decade. These include the Law Relating to Public Health Care Services 2007, the Control of Smoking and Consumption of Tobacco Law 2006, the Body Organ Donation Law 2004, the Blood and Blood Products Law 
2003 and the National Food Law 1997. A Department of Medical Research investigates issues such as malaria, snake bites and viral hepatitis. As of 2001, there were 742 hospitals (six hospital beds per 10000 people), 1412 rural health centres $^{4}$ and 348 maternal and child welfare centres, in addition to health interventions provided by international NGOs (WHO 2005). The public health system also bears the brunt of casualties of the country's significant production and consumption of opium, heroin and methamphetamines. There are 26 major drug treatment centres and 40 minor ones throughout the country. ${ }^{5}$

Traditional medicine has been and remains a priority area for the previous and current military council and the healthcare system is designed to integrate traditional medicine through all levels of community health care, including education, training, registration, licensing and research. Fourteen traditional-medicine hospitals ${ }^{6}$ exist in all divisions except for Chin State, and there are 43 district clinics and 213 township medical clinics. The Traditional Medicine Council Law of 2000 requires licensing for traditional-medicine practitioners, and that they hold either a Diploma or Bachelor of Myanmar Traditional Medicine. ${ }^{7}$ Such qualifications are obtainable from the University of Traditional Medicine in Mandalay, which opened in $2001 .^{8}$ In addition, there is a national herbal park at Naypyitaw, a traditional medicine museum and indigenous medicine pharmaceutical factories. ${ }^{9}$ In line with medical training in several other Asian countries, since 2003, the Bachelor of Medicine degree incorporates 36 hours of traditional-medicine teaching in the third year of the curriculum.

This official creation of a two-tier medical system of public and private health care rarely acknowledges a shadow two-tier system that has come to exist: that of the military and civilian divisions of health care. This divide has emerged in the contrast between free or low-cost health care of a reasonable standard in the high-tech military hospitals and the poorly funded public health system.

Military hospitals feature prominently in the state media in terms of receiving donations of biomedical equipment and showcasing the health system to international visitors. This is in contrast with the small amount of information available about the public health system. Recent reports about the general hospital in the capital of northern Kachin State, Myitkyina Government Hospital, offer a rare glimpse of working conditions. A lack of electricity has meant that delivery rooms have operated via torchlight except for two hours each evening. The Kachin News Group (2007) recently reported that patients requiring surgery needed to pay 7500 kyat (\$US6) an hour for the use of the hospital-owned generator. This contrasts with the medical health infrastructure that has been created in the new capital of Naypyitaw, including a 1000-bed general hospital and numerous private clinics. 


\section{Patterns of health seeking}

Beyond the division of the Burmese medical system into government versus private and military versus civilian sectors, the medical system can be broken down into the categories shown in Table 11.1.

Table 11.1 Myanmar medical system

\begin{tabular}{|c|c|c|c|c|}
\hline \multicolumn{3}{|c|}{ Government } & \multicolumn{2}{|l|}{ Private } \\
\hline Military & Biomedicine & & Private Companies & $\begin{array}{l}\text { Hospitals, Cardiac, } \\
\text { Cancer, Dental, } \\
\text { Diagnostic, Pathology }\end{array}$ \\
\hline \multirow[t]{8}{*}{ Civilian } & Biomedicine & $\begin{array}{l}\text { Para-statal } \\
\text { groups } \\
\text { (USDA, MRC } \\
\text { MMCWA), } \\
\text { ministries }\end{array}$ & UN, INGOs, Local NGOs & $\begin{array}{l}\text { Foreign doctors and } \\
\text { volunteers }\end{array}$ \\
\hline & \begin{tabular}{|l|} 
Traditional \\
Medicine
\end{tabular} & & $\begin{array}{l}\text { Trans-National Health } \\
\text { Providers }\end{array}$ & $\begin{array}{l}\text { Emergency health, } \\
\text { Reproductive health, } \\
\text { Trauma services }\end{array}$ \\
\hline & & & $\begin{array}{l}\text { Ayurvedic/Humoral } \\
\text { Medicine }\end{array}$ & \\
\hline & & & $\begin{array}{l}\text { Traditional Medicine } \\
\text { Practitioners }\end{array}$ & Lethe (midwives) \\
\hline & & & Buddhist Sects (gaing) & $\begin{array}{l}\text { Bodaws, Weikza, Occult } \\
\text { practices }\end{array}$ \\
\hline & & & Astrology & \\
\hline & & & Magical Healers & $\begin{array}{l}\text { Alchemy, Inn Saya, Dat } \\
\text { Saya, Medaws, Payawga } \\
\text { Saya }\end{array}$ \\
\hline & & & Other Healing Systems & $\begin{array}{l}\text { Wa, Karen, Naga healers, } \\
\text { etc. }\end{array}$ \\
\hline
\end{tabular}

From the starting point of the user, given this complexity and unevenness of coverage, quality and cost, it is not surprising that competing and contradictory logics govern the use of this medical system. Some families bypass this system altogether. These are the high-ranking military officers and their families who are able to use the military's clinics, hospitals and diagnostic services, and hospitals in Singapore and Bangkok for complicated interventions and surgery. This is a trend also followed by the very small Burmese middle class. In border areas, it is common to cross into neighbouring countries to seek treatment.

Most Burmese, however, cannot leave the country and, for the majority rural population, the combination of poverty and the scarcity of trained medical personnel mean that local remedies and practitioners are the only options. As a general rule, decisions about illness are made within co-located families. In the first instance, Burmese most often seek symptomatic relief through dietary changes, pharmaceuticals and traditional medicines. In villages, the level of knowledge of traditional medicine is dependent on the personal interests of individual villagers. This knowledge has become very unevenly distributed with neighbouring villages having very different patterns of resort to health care. In some villages, elders pass traditional-medicine recipes to their children 
and they become unofficial consultants when illnesses occur. ${ }^{10}$ In other villages, lacking such knowledge, the village shop stocks common pharmaceuticals that provide symptomatic relief, such as pain and anti-inflammatory medication.

When initial symptomatic relief fails, a gradual change through dietary modification is employed (this is often practised concurrently with other remedies). This homeopathic system is similar to Indian Ayurvedic ${ }^{11}$ practices, but is a more gentle and altogether less systematic practice in Burma. The comprehensive nature of the Ayurvedic system has been largely lost in Burma with the decline of indigenous medical practitioners after British colonisation. Complicating this approach to health care is the simple fact that most Burmese are well aware of the need to include, for example, more protein and a greater variety of vegetables in their diet, but they are prevented from doing so due to food scarcity and poverty.

Biomedicine is increasingly the first medical system that Burmese turn to for disease treatment - with two provisos. The first is that the cost of biomedicine puts all but the simplest consultations and treatment regimes out of the range of most of the population. The second is the great fear of surgery in Burma, whereas other forms of bodily penetration such as the insertion of gold needles under the skin as a form of alchemical treatment, tattooing and, more recently, biomedical injections, are readily tolerated. The great appeal of biomedicine, ${ }^{12}$ especially in the form of pharmaceutical injections, is the rapidity of symptomatic relief, which is often equated with magic, as the response can be so dramatic. This sensation is further enhanced by the comparison with the more gradual changes that occur through dietary and homeopathic healing systems. This logic has been extended by many Burmese to include the use of multivitamin and B-vitamin injections to counter some of the effects of malnourishment.

Most Burmese do not have such options. A great deal of illnesses fit into a range of 'bad fortune' that can include a spate of bad luck or a belief in being cursed, bewitched or under the power of various malevolent spirits. These illnesses are the domain of a veritable smorgasbord of occult healers, a significant number of whom are Buddhist monks. A common healing forum is the Burmese gain. A gain is a 'term referring to a group of people organised around a founder' (Tosa 2005:155). The gain founder is most often believed to be a wizard (weikza) possessing supernatural powers obtained through mastery of occult law and practices (Skidmore 2004:183-4). Gain membership and the proliferation of gain decreased after a law was issued during the Ne Win era banning monks from practising medicine and a separate law banning gain (Tosa 2002). The leadership (and revolutionary) potential of charismatic gain leaders and other individuals claiming occult mastery is a common theme in Burmese history (Houtman 2005:136). In fact, bronze statues of Saya San, a healer who led a rebellion against the British in the Ayeyarwady Delta in the 1930s, have been commissioned by 
the Department of Traditional Medicine and stand proudly outside traditional-medicine clinics and buildings. Such charismatic gain and other occult practitioners sit on the right of Table 11.1. Not everyone utilises these practitioners and urban dwellers rarely, if ever, move any further to the right of the table than consulting an astrologer, except for life-threatening illnesses. ${ }^{13}$ Life-threatening diseases such as cancer or HIV/AIDS provide clear evidence of the patterns of resort to healers used by Burmese people. A great many of the hundreds of patients the author has interviewed in Yangon in the past decade or so begin in the folk and traditional medicine traditions then start spending large amounts of money in the biomedical sector once their disease progresses to a debilitating stage. This includes, for example, bowel cancer that has necessitated surgery and then the use of a colostomy bag. Another example is HIV-positive patients whose disease has progressed to the stage of almost no immune function. These patients run out of money very quickly and that is the stage when they exit the biomedical sector.

This leaves dying patients with the options of faith, religion, miraculous cure or supernatural intervention. It also leaves these patients open to practices such as the drinking of mercury-infused juices, in the case of HIV/AIDS patients being treated by alchemists, which can cause a faster decline and further compromise a failing immune system. Palliative care then becomes necessary and families, religious institutions and a very small number of government services provide end-of-life care for patients (many of whom are dying from diseases that could have been cured or slowed if they had been treated adequately at a much earlier stage).

The use of, or engagement with, the health system then depends on a host of variables, the foremost of which are money and military or civilian status; but ethnicity, previous health experiences, exposure to biomedicine, fear of surgery, belief in magical and religious healers, belief in spiritism, the location of the patient and the severity and stage of illness or disease all play determining roles.

So far this chapter has described the outward composition of the medical system and the factors that govern access to and use of the system by Burmese patients. It has done so within the framework of national health policies and the complexity of providers. The other aspects of the healthcare system that are covered next are rarely considered core business by healthcare providers, but they are essential to an integrated understanding of Burmese healthcare needs.

\section{Humanitarian and medical aid}

The first of these broader factors are the forms of emergency medical, humanitarian and health-development programs provided by international and national NGOs and UN agencies in-country. The first NGOs to begin work in Burma, Médecins sans Frontières and World Vision International, began 
operations in 1992. Aid provision within Burma has been scaled up significantly in the past five years, despite international economic sanctions against the regime and the limited mandates of organisations such as the International Labour Organisation (ILO), the UN Development Program (UNDP) and the UN Office on Drugs and Crime (UNODC). The politicised nature of aid and the restrictions on international aid workers have meant that community-based and local NGOs have become channels for aid. It also means that many aid agencies have aligned themselves with government organisations in quasi-partnerships that have significant ethical dimensions. Transparency and impartiality have thus been key to the continuing effort to expand aid and monitoring by UN agencies in recent years.

A recent rapid appraisal of the humanitarian situation in Burma has noted that the humanitarian situation needs to be reconceptualised from one of human security to one of social security, emphasising the need for and partial success in recent years of the UN agencies and other organisations in pushing back or at least containing the Burmese state's continuing attempt to penetrate all aspects of the civil sphere (Duffield 2008). Duffield (2008:41) argues for a rationalisation of international aid architecture in Burma to increase the range and depth of social welfare support'. This suggestion is all the more cogent given the State Peace and Development Council's (SPDC) increasing view of many forms of international humanitarian aid as either potentially or actively subversive of the military's continuing rule.

Duffield's report highlights the fragile, broken and often non-existent public welfare and health system in Burma and the significant role that international aid is playing in propping up, extending and establishing basic health services in the absence of a public welfare system.

\section{Human rights abuses}

The second of these broader factors are the serious core human rights abuses cited by the Human Security Report (Human Security Center 2005). A great number of aid and activist organisations have documented the political and economic context of human rights violations as part of establishing the parameters of the humanitarian crises in Burma. ${ }^{14}$ There is also an international public health and epidemiological perspective on human rights issues in Burma, particularly on Thai-Burma border populations (Beyrer and Stover et al. 2007; Beyrer 1998; Belton and Whittaker 2007). Reading the countless reports from these organisations about the death, torture and lack of access to health of forcibly displaced and refugee populations, there can be no doubt that Burma is a country currently in the midst of a medical and humanitarian crisis. The current health system is unable to deal with let alone reduce human rights abuses. It is not just a case of too few facilities, resources and trained personnel. It is also the pervasive 
fear of retribution for health personnel who knowingly treat and give aid to activists, opposition politicians and all those who agitate for democracy.

\section{Transnational and cross-border health care}

Sufferers of human rights abuses, such as tortured political prisoners or land-mine victims, pour illegally across the nation's borders, most often into Thailand. The third of these broader issues, then, concerns the dual nature of aid provision to Burma: a recent significant increase in in-country aid as well as competing funding regimes for the provision of cross-border and transnational health care.

In the civil war areas of eastern Burma, Neumann and Bodeker (2008) describe a revitalisation of traditional Karen medical knowledge and practices, in part because of acute shortages of pharmaceuticals and biomedicine. Their work has documented how Buddhist monks provide spiritual and mental health care and explores the ways in which traditional healers are working to fill healthcare gaps in the region. The Wa also depend in large part on traditional health practices and Magnus Fiskesjö (2008) has written of how this corpus of knowledge and practice has fared in its encounter with modern medicine, as well as how it has been disrupted significantly by forced relocations and the detrimental impact on the capacity of the Wa to build on their own traditions and to access adequate health care. These studies are significant because of the difficulty of conducting scholarship on health issues outside central Burma.

The provision of emergency health care and infectious-disease prevention programs exists outside Burma's formal healthcare system. Cynthia Maung and the Back Pack Health Worker Team (BPHWT) and researchers such as Naing (2008) and Suzanne Belton (2008) cover the provision of aid within war zones, the HIV/AIDS epidemic in Burma and Thailand and emergency care for reproductive health issues in refugee populations. Maung and the BPHWT have described a dire healthcare situation in eastern Burma, where long-term, low-intensity conflict has given rise to a state of 'chronic emergency' (see Mahn Mahn's chapter in this volume). Their work shows how, in some parts of Burma, major public health issues arise as a direct result of civil conflict and widespread human rights abuses perpetrated by armed groups. Forced displacement, forced labour and the destruction of food supplies are only a few of the human rights violations that have a significant impact on health in this region. Belton's work has been located around the Thai-Burma border refugee camps, where Karen and other Burmese refugees encounter particular reproductive-health needs and challenges. The Mae Tao Clinic in Mae Sot works to identify and address these, providing important treatment, education and supplies to thousands of Burmese patients. Naing has analysed the HIV/AIDS epidemic affecting many Burmese migrant fishermen in Thailand, with an interest in developing effective prevention programs among those at risk. Other programs exist in neighbouring countries to aid Burmese working in the sex industry, victims of human 
trafficking and those who are affected by the 2004 tsunami-most particularly illegal migrants in and around Phuket in Thailand.

The failure of the State to provide accessible health care means that the roles of globalisation and transnationalism cannot be understated in the provision of emergency and preventive health care as well as the availability of medicines. The flow of illegal, unregulated medicines, some requiring cold-chain facilities and injectable vaccines containing attenuated viruses, is directed into Burma from all of its neighbours. In the modern pharmacies of Mongla in Wa State, for example, medical products from multinational companies such as Johnson and Johnson with Chinese script are available (Skidmore and Nordstom forthcoming). In the markets of Yangon, skin-whitening creams from India are sold beside heart medication from Thailand and psychiatric medications such as chlorpromazine and lithium manufactured in China (Skidmore 1998). ${ }^{15}$

Mongla is only one border town on the centuries-old southern Silk Route with significant numbers of Burmese people crossing the border on a daily basis. Burmese people similarly cross into the Indian state of Manipur through the Burmese border town of Tamu, and into Thailand via a series of busy border crossings. Medicines and illegal drugs and pharmaceuticals are carried across the region through these old trading routes (Skidmore and Nordstrom forthcoming). The help-seeking patterns of Burmese who live in proximity to border crossings thus contain more options than those living in the nation's central river valleys.

\section{Conclusion: human rights and the right to health}

As in other developing nations, particularly in Africa, in Burma, a substantial proportion of government medications and preventive-health materials are sold on the black market. The theft of medical equipment, medicines and other products from international and UN organisations means these products can be purchased easily in Yangon's main markets.

The transparency of aid delivery and the provision of materials from international donors are issues that continually confront in-country aid providers. The Australian medical practitioners currently working in Burma (Myanmar/Burma Update 2007) attest to the latent capacity and talent still evident among the Burmese medical fraternity, but the cost of health care, the continuing exodus of qualified medical personnel, the loss of much traditional knowledge since the colonial period and the existence of conflict zones within the country are all factors contributing to limit Burmese people's access to health care. Taken as a whole, the possibility of affordable, accessible and evidence-based health care is extremely limited for the majority of Burma's 54 million inhabitants. In this context, it is not surprising that Burmese people turn to folk and magical forms 
of medical practices, such as exorcists, alchemists and wizardry, when they have exhausted their financial resources and cannot find relief.

In the wake of the suppression of the so-called 'Saffron Revolution' in September-October 2007, it is perhaps timely to conclude with some thoughts about the long-term consequences of the lack of a right to health. There is indisputable photographic evidence of shootings and beatings administered to protestors during the attempted Saffron Revolution ${ }^{16}$ and the former UN Special Rapporteur on Human Rights in Myanmar, Sergio Pinheiro, put the death toll at 31 with up to 4000 arrested and 1000 still detained as of 11 December 2007 (UNHRC 2008:4). In earlier work (Skidmore 2005, 2003), I described the long-term consequences of inculcating a state of fear and of perpetual vulnerability in the urban populace. Since September 2007, there has been a demonstrable increase in the efficiency by which terror, as distinct from fear, can be created among the population. In other countries in which violence has been perpetrated and witnessed, there are well-documented harvests of suicide, trauma and mental health problems. It is not possible to gather such health data in Burma, yet psychological health must surely be considered when describing Burma's humanitarian and health crises. Paranoia, nightmares, confused and impaired thinking and psychological defences such as denial are also prevalent among the Burmese I have interviewed in the wake of the violence in Yangon (Skidmore 1998). Jail terms for monks and civilians who took part in the demonstrations, as well as reports of torture within prisons and harsh sentences to prison and labour camps, have together created a pathological psychological climate. In Yangon, the anger that Burmese Buddhists feel at the continuing barricading and closure of monasteries and the continuing arrests of monks is palpable. To seek health care for trauma and fear, however, is to risk charges of subversion and treason.

In making these comments about the mental health of the urban populace, the purpose is not to detract from the serious human rights issues that occur among forcibly displaced civilian populations in Burma's civil war zone. In addition to the significant volume of core human rights abuses occurring in Burma, however, is a virtually undocumented and untreated epidemic of psychological trauma. This psychological trauma is a crucial aspect of a lack of a right to health and it is in part related to the subversion of medical ethics that is required of Burmese people who train and practice medicine in Burma today. There are precious few provisions for psychological, psychiatric or counselling help for those suffering from the long-term effects of living in a state of fear. At times of crisis such as during the September 2007 street protests against cost-of-living increases and military rule, anxiety, fear and paranoia can become acute, but medical personnel also live in fear of giving aid to people branded as enemies of the State or criminals during these moments of resistance. 
The latter part of this chapter documents forms of health care offered by non-state providers, but also the forms of illness and disease that are not permitted to exist and therefore to be treated. It does so to emphasise not just the patent inadequacy of the current regime's expenditure on health care, but to draw attention to the continuing denial of the fundamental right to health for the majority of the population.

\section{Epilogue}

On 2 May 2008, as this volume was being finalised, severe tropical Cyclone Nargis made landfall in Ayeyarwady Division at near peak intensity. Winds were measured at the height of the cyclone at 215 kilometres an hour. The cyclone passed just to the north of Yangon. Within the Ayeyarwady Delta, the storm caused a tidal surge of up to four metres, inundating paddy fields with sea water.

The death toll from the cyclone is staggering, with official figures of 130000 dead and 2.4 million people affected. The United Nations believes it left 900000 people homeless. ${ }^{17}$ It seems clear that a large number of children and elderly Burmese are among the dead. The cyclone caused extensive damage to towns and villages in the delta as well as in Yangon and its peri-urban townships.

The cyclone developed on 27 April and Sri Lankan, Bangladesh and Burmese authorities issued warnings. The Bangladesh Government, for example, urged farmers to finish bringing in their rice harvest (Voice of America News, 29 April 2008). In Burma, the military regime issued warnings on 2 May that a severe cyclonic storm was over the Bay of Bengal. It concluded with the comment that '[w] eather is partly cloudy to cloudy in the Andaman Sea and elsewhere in the Bay of Bengal' (New Light of Myanmar, 2 May 2008).

While the inadequacy of the government warnings became patently obvious when approximately 95 per cent of all structures within the delta were destroyed by Nargis, the regime's response to the disaster received strong international condemnation. The British Prime Minister labelled the aftermath of the cyclone a 'man-made catastrophe' (The Irrawaddy, 21 May 2008) because of the regime's refusal to allow international disaster-relief teams to provide emergency aid. The military regime blocked the access of crucial supplies, which probably caused the death and suffering of numerous people. The number of people who died in the aftermath of the cyclone because of the regime's refusal of aid and its inability to reach survivors in time might never be known. It is clear, however, that the SPDC does not have disaster-relief planning capability or emergency supplies and that it deliberately withheld international aid to Cyclone Nargis survivors.

This chapter describes a withholding of the right to health from the Burmese people as a human rights abuse on an enormous scale. The charge of crimes against humanity must be proven over a sustained period as a deliberate policy. 
This chapter has sketched the outline of a comprehensive failure to provide for the health needs of the Burmese population and of 46 years of continuing human rights abuses perpetrated by the military regime and its paramilitary, militia and security forces and organisations. The military regime's response to the loss of life and emergency humanitarian needs generated by Cyclone Nargis raises the spectre of a lack of a right to health in contemporary Burma as a continuing, sustained and often systematic form of a crime against humanity.

\section{References}

Belton, S. 2008, 'The Reproductive Health Crisis Among Burmese Refugees' in Monique Skidmore (ed.), Medicine in Myanmar: Past and present, Nordic Institute for Asian Studies Press, Copenhagen.

Belton, S. and Whittaker, Andrea 2007, 'Kathy Pan, sticks and pummelling: techniques used to induce abortion by Burmese women on the Thai border', Social Science and Medicine, vol. 65, no. 7, pp. 1512-23.

Beyrer, C. 1998, War in the Blood: Sex, politics, and AIDS in Southeast Asia, White Lotus, Bangkok.

Beyrer, C. and Stover, E. et al. 2007, The Gathering Storm: Infectious diseases and human rights in Burma, Human Rights Center, University of California, Berkeley, and Center for Public Health and Human Rights, Johns Hopkins Bloomburg School of Public Health.

Child Soldiers International (CSI) 2004, Global Report 2004: Myanmar, viewed 22 May 2008, $<$ http://www.child-soldiers.org/library/global-reports?root_id=159\&directory_id=165>

Duffield, M. 2008, On the edge of 'no man's land: chronic emergency in Myanmar, Working Paper No. 01-08, Centre for Governance and International Affairs, University of Bristol.

Fiskesjö, M. 2008, in Monique Skidmore (ed.), Medicine in Myanmar: Past and present, Nordic Institute for Asian Studies Press, Copenhagen.

Friends of the World Food Program (FOWFP) 2008, Q\&A with World Food Program Country Director for Myanmar, Chris Kaye, January 2008, $<$ www.friendsofwfp.org/site/pp.asp?c =7oIJLS Os G pF\&b=3594603>

Houtman, G. 2005, 'Sacralizing or demonizing democracy? Aung San Suu Kyi's "personality cult"', in Monique Skidmore (ed.), Burma at the Turn of the Twenty-First Century, University of Hawai'i Press, Honolulu, pp. 133-53.

Human Security Center 2005, Human Security Report 2005: War and peace in the twenty-first century, Human Security Centre, University of British Columbia, Canada. 
Kachin News Group 2007.

McGeown, K. 2005, 'Aid in Burma: when it's time to give up', BBC News, 25 September, <http://news.bbc.co.uk/2/hi/asia-pacific/4268618.stm>

Naing 2008, 'Burmese fishermen and HIV prevention programs', in Monique Skidmore (ed.), Medicine in Myanmar: Past and present, Nordic Institute for Asian Studies Press, Copenhagen.

Neumann, C. and Bodeker, G. 2008, 'Karen healing beliefs and practices', in Monique Skidmore (ed.), Medicine in Myanmar: Past and present, Nordic Institute for Asian Studies Press, Copenhagen.

New Light of Myanmar 2005.

New Light of Myanmar, 2 May 2008, viewed 2 June 2008, <http://www.wunderground.com/hurricane /2008/nargisnews.jpg>

Skidmore, M. (ed.) 2005, Burma at the Turn of the Twenty-First Century, University of Hawai'i Press, Honolulu.

Skidmore, M. 1998, Flying through a skyful of lies: survival strategies and the politics of fear in urban Burma (Myanmar), PhD Dissertation, McGill University.

Skidmore, M. 2002, 'Menstrual madness: women's health and well-being in urban Burma', in A. Whittaker (ed.), Women's Health in Mainland Southeast Asia, Haworth Medical Press, New York, pp. 81-99.

Skidmore, M. 2003, 'Darker than midnight: fear, vulnerability and terror making in urban Burma (Myanmar)', American Ethnologist, vol. 30, no. 1, February, pp. 5-21.

Skidmore, M. 2004, Karaoke Fascism: Burma and the politics of fear, University of Pennsylvania Press, Philadelphia.

Skidmore, M. and Nordstrom, Carolyn (forthcoming), Public culture.

Talikowski, Luke and Gillieatt, Sue 2004, 'Female sex work in Yangon, Myanmar', Sexual Health, vol. 2, no. 3, pp. 193-202.

The Irrawaddy, 21 May 2008, viewed 2 June 2008, <http://www.irrawaddy.org/opinion_story.php?art_id=12166>

Tosa, K. 2002, Weikza: the case of Thamanya Taung Hsayadaw, Essay presented at Burma Studies Conference Burma-Myanmar Research and its Future, 21-25 September, Gothenburg, Sweden.

Tosa, K. 2005, 'The chicken and the scorpion: rumor, counternarratives, and the political uses of Buddhism', in Monique Skidmore (ed.), Burma at the Turn of the Twenty-First Century, University of Hawai'i Press, Honolulu, pp. 154-74. 
Transparency International 2007, Persistent corruption in low-income countries requires global action, Press release, 26 September, Transparency International, London/Berlin, pp. 1-3.

United Nations Human Rights Council (UNHRC) 2008, Report of the Special Rapporteur on the Situation of Human Rights in Myanmar, Paulo Sérgio Pinheiro, Mandated by Resolution 6/33 of the Human Rights Council, viewed 3 June 2008, <http://burmalibrary.org/docs4/SRM-HRC-7-24-en.pdf>

United Nations Office on Drugs and Crime (UNODC) 2007a, Opium Poppy Cultivation in Southeast Asia: Lao PDR, Myanmar, Thailand, United Nations Office on Drugs and Crime, New York.

United Nations Office on Drugs and Crime (UNODC) 2007b, World Drug Report, United Nations Office on Drugs and Crime, New York.

Voice of America News, 29 April 2008, viewed 2 June 2008, $<$ http://voanews.com/english/archive/ 2008-04/2008-04-29-voa19.cfm?CFID=59893764\&CFTOKEN=32487379>

World Health Organisation (WHO) 2000, World Health Report 2000: Health systems - improving performance, World Health Organisation, Geneva.

World Health Organisation (WHO) 2005, World Health Report 2005: Make every mother and child count, World Health Organisation, Geneva, viewed 22 May 2008, <http://www.who.int/whr/2005/whr2005en.pdf>

World Health Organisation (WHO) 2006, World Health Report 2006: Working together for health, World Health Organisation, Geneva.

World Health Organisation (WHO) 2007, World Health Report 2007: A safer future, global public health security in the $21^{\text {st }}$ century, World Health Organisation, Geneva.

Zeller, F. 2007, 'Food shortfall looms in crisis-hit Myanmar, UN warns', Agence France-Presse, 3 October.

\section{Endnotes}

1 The World Health Organisation (WHO) has not conducted overall health performance rankings since 2000 as the ranking system proved controversial among member states.

2 The 2007 Corruption Perceptions Index ranks 180 countries in terms of perceived levels of corruption. Burma ranks equal last with Somalia out of the 180 countries assessed.

${ }^{3}$ Opium poppy cultivation has decreased by 83 per cent in nine years, from 130300 hectares in 1988 to 21500 ha in 2006. Poppy cultivation is, however, again on the rise, with a 29 per cent increase in cultivation in 2007 to 27700 ha and a 46 per cent increase in production due to higher yields. Methamphetamine production appears to be continuing to increase rapidly with 19.1 million pills seized in the country in 2006 compared with 3.6 million in 2005 (UNODC 2007b).

4 There were also 350 dispensaries, 86 secondary health centres and nine medical institutes.

5 In addition, there are six Regional Drug Abuse Rehabilitation Centres and two Youth Rehabilitation Centres (New Light of Myanmar 2005). 
6 Two of these hospitals have 50 beds; the remainder have 16 beds.

7 Related laws are intended to regulate the quality and sale of indigenous medicines.

8 Before this there was an Institute of Traditional Medicine in Mandalay, which opened in 1976, and later a similar institution in Yangon.

9 There are an estimated 9000 herbal and medicinal plants now being grown throughout the country.

10 An exception to this rule appears to be knowledge of emmenagogues - medications taken to induce miscarriage or as a method of fertility regulation (Skidmore 2002).

11 Ayurvedic medicine is an ancient philosophy of health care native to the Indian subcontinent, sometimes considered as a Hindu system of health care because it derives from the oral advice on living in the Hindu Vedas. It is used by millions of people in India, Nepal, Sri Lanka and increasingly in the West and is known widely as the world's oldest continuously practised system of medicine. 'Ayurveda' translates roughly as 'wisdom for living' or 'knowledge of long life'.

12 Biomedicine, or 'Western' medicine, is called Ingleik medicine in Burma as it was most widely introduced by British colonisers.

13 I have interviewed a very broad cross-section of Burmese people, including retired senior government ministers and opposition political party members and followers, who have been suffering terminal illnesses and have sought treatment from magical healers.

14 These organisations include the United Nations, the Thai-Burma Border Consortium, the Karen Human Rights Group, Human Rights Watch Asia, Amnesty International, Médecins sans Frontières and the Back Pack Health Medical Team.

15 A survey of family-run businesses in Thein-byu Ze, one of Yangon's main markets, shows that importers of raw materials for indigenous Burmese medicines source their products from more than 20 different countries (Skidmore 2003, unpublished field notes). Iran, for example, is only one of the many countries with which Burmese merchants have long-established trading relationships. Indigenous Burmese medicine is sent to what is commonly called the 'border line', meaning the official land exit points from Burma. These are mainly on the Chinese and Thai borders. Traders in border towns such as Tachilek then send the indigenous medicines around the world. In these efforts, Burmese traditional-medicine manufacturers and exporters are eagerly supported by the military regime. The pinnacle of such support occurred during the ascendency of the former Prime Minister, General Khin Nyunt, who was the patron and chair of the Traditional Medicine Council and who realised the multimillion-dollar industries in traditional medicine that existed in neighbouring China and India.

16 See, for example, the web pages of activist news organisations such as the Democratic Voice of Burma and the Irrawaddy Magazine.

17 See UN Office for the Coordination of Humanitarian Affairs (OCHA) web site for Situation Reports. 